\title{
Effect of compound and single-based fertilizers on shelf life of exotic/minor vegetable crops cultivated for the fresh market
}

\begin{abstract}
Laboratory studies were conducted to ascertain the shelf life of fresh lettuce (var. Eden), carrot (var. Bahia), and sweet pepper (var. Yellow wonder) as influenced either by a singlebased fertilizer or a compound fertilizer for optimal fertilization towards enhanced shelf life quality. This was accomplished following Completely Randomized Design (CRD) with four replications.Samples of lettuce were harvested from a $71 \mathrm{~kg}, 100 \mathrm{~kg}$, and 128 $\mathrm{kg}$ of ammonium sulphate $(20.5 \% \mathrm{~N}, 23.4 \% \mathrm{~S}) /$ ha single-based treated plots, $350 \mathrm{~kg}$ of NPK (15-15-15)/ha compound treated plot, and control/no fertilizer application; samples of sweet pepper were harvested from an $81 \mathrm{~kg}, 100 \mathrm{~kg}$, and $138 \mathrm{~kg}$ of 6-24-12 NPK/ha singlebased treated plots, $225 \mathrm{~kg}$ of NPK (15-15-15)/ha compound treated plot, and control; and samples of carrot were harvested from a $43 \mathrm{~kg}, 71 \mathrm{~kg}$, and $100 \mathrm{~kg}$ of 10-10-30 NPK/ ha single-based treated plots, $225 \mathrm{~kg}$ of NPK (15-15-15)/ha compound treated plot, and control.The different rates of the single-based fertilizers and the corresponding controls resulted in long shelf life as opposed to the short shelf life obtained by the application of compound fertilizers. In all cases it was one more week.
\end{abstract}

Volume 5 Issue 2 - 202I

\author{
Moomin Abu \\ Department of Horticulture, Faculty of Agriculture, University \\ for Development Studies, Ghana
}

Correspondence: Department of Horticulture, Faculty of Agriculture, University for Development Studies, P. O. Box TL 1882, Nyanpkpala, Northern Region, Ghana, Tel +233244849469, Emailmoonabu@yahoo.com

Received: April 01, 2021 | Published: April 15, 2021

Keywords: compound fertilizers, single-based fertilizers, shelf life, exotic/minor vegetable crops, fresh market

\section{Introduction}

Consumers in the past few decades have become increasingly concerned about the quality of the food produce and products they are consuming. Researchers have therefore investigated the impact of plant nutrition on the quality of fruits and vegetables produced. According to Singh et al. ${ }^{1}$ nutrients significantly impact on fruit colour, texture, disease susceptibility, juice composition, and the development of physiological disorders which has direct effect on shelf life. According to these authors, fruit quality usually improves as soil moisture and nutrients increase from deficiency to optimum. The authors added that nutrient levels that produce maximum yield may not always correspond to those that result in the highest fruit quality and maximum quality retention, and that poor management of fertilizers will increase physiological disorders dueto deficiencies of some nutrients or increases of other nutrients that may lead to toxicity and subsequent poor shelf life.

Postharvest management starts with pre-harvest managements. Bekele $^{2}$ reiterated that once fruits and vegetables are harvested the overall quality can hardly be improved but could only be maintained. The final market value of the produce and acceptance by the consumers depends on the grower's ability to apply best available preharvest technology followed by harvesting and the application of best available postharvest handling practices. ${ }^{2}$ Barman et al. ${ }^{3}$ outlined preharvest factors influencing postharvest quality to include frequency of irrigation, use of fertilizers, pest control, growth regulators, climatic conditions like wet and windy weather, natural climates such as hailing, high wind velocity, heavy rainfall, and crop condition (age, training, light penetration, etc). These factors influence overall produce quality and suitability for storage by modifying the physiology, chemical composition, and morphology of the produce. ${ }^{3}$
The quality traits required or purpose for which the crop is grown will help in selecting not only the type of fertilizer but the quantity used during production. Postharvest quality of fresh vegetables generally depends on the quality achieved at time of harvest. Vegetable quality is also influenced by a plethora of preharvest factors including the genetic and environmental components. ${ }^{4,5}$ According to these authors the effect of preharvest factors on postharvest produce quality impact greatly on both individual plants and plant communities.

Vegetable producers optimize yields and crop quality by the application of selected cultural practices. Nonetheless, Lodhi et al. ${ }^{6}$ stated that plant nutrition technics in particular, has been shown to greatly impact produce storage life. Soil and plant water availability, and relative humidity also play a vital role in determining crop quality; such as the influence of low relative humidity on water potential gradients between vegetable tissues and the external environmental air. As water is lost from the plant, water flows through the leaves, thereby limiting supplies of water and nutrients to fruits and other edible parts. Nayyer et al. ${ }^{7}$ has shown that low relative humidity can result in differential partitioning of calcium and boron in vegetables which result in nutritional disorders such as blossom-end rot of tomato fruits and tip bum of leaves of lettuce. The extent of these produce health disorders depends on the environment, water availability, and cultivar under investigation.

Appropriate rates/levels of soil nitrogen can result in improved quality of vegetables, generally by allowing for the development of sufficient photosynthetic surface area in higher plants. For example, Cuquel et al. ${ }^{8}$ reported that nitrogen application at a recommended rate improved head quality in broccoli (Brassica oleracea L., Botrytis Group). Salunkhe et al. ${ }^{9}$ also reported that the application of nitrogen fertilization at a recommended rate generally resulted in increased nitrate concentration in edible plant parts. On the other hand, excessive 
nitrogen levels have been associated with storage disorders and poor quality of harvested produce. In broccoli, increased incidence of hollow stems followed high nitrogen application and in sweet potato [lpomoea batatas (L.) Law.], increased weight loss during storage was closely related to nitrogen application..$^{10}$ Maynard ${ }^{11}$ also found that excessive $\mathrm{N}$ fertilization caused accumulation of potentially hazardous concentration of nitrate nitrogen which adversely affected the nutritional quality spinach (Spinacia oleracea L.).

Studies have shown that calcium deficiency causes many important physiological disorders affecting the postharvest quality of many vegetable crops, including tip burn in leafy crops, blossomend rot in solanaceous species, and blackheart in celery. ${ }^{4}$ Other storage disorders of vegetable crops also relate to deficiencies or toxicities of micronutrients that affect nutritional quality and subsequent shelf life of the fresh produce. ${ }^{9}$ According to these authors deficiencies or toxicities of boron, copper, and molybdenum, in particular, are associated with specific vegetable disorders.

Johnson et al. ${ }^{12}$ reported that spinach cultivars were produced under normal and high rainfall conditions and then evaluated for shelf life and other postharvest quality attributes. High rainfall during the growing season reduced spinach storage potential by an average of $40 \%$. Plant type (savoy vs. common) and temperature did not have an effect on postharvest storage potential. ${ }^{12}$ Salunkhe et al. ${ }^{9}$ reiterated that generally, fruits and vegetables that have a shorter production season and mature early have a shorter storage life than slow-maturing ones. $^{9}$

Although the effects of temperature extremes encountered in the field could be technically managed through the use of protective strategies such as irrigation and floating row-covers, most producers are unable to effectively apply that. Therefore, we will consider temperature as an unmanageable environmental factor and instead focus on a cultural practice such as plant nutrition technics and the effect on vegetable produce quality.

Brady and Weil ${ }^{13}$ reported that inorganic fertilizers have higher concentrations of nutrient elements than organic fertilizers and that since nitrogen, phosphorus, and potassium must be taken up by plants in the inorganic forms, inorganic fertilizers are immediately bioavailable to plants without modification. Nair ${ }^{14}$ reiterated that usually, nutrition experiments focus mostly on yield and quality. That is why such experiments mostly deal with the main macronutrients $(\mathrm{N}, \mathrm{P}, \mathrm{K})$, as well as with $\mathrm{Ca}, \mathrm{Mg}$, and Sand some micro-nutrients in a lesser perspective; considering that both macro and micronutrients are crucial for produce quality and shelf life. ${ }^{14}$ However, micronutrients requirements are very little and it is always very easy to exceed the normal requirements, especially with field trials. Hence, the need to research into shelf-life assessment as a collateral issue with the objective to determine the effect of compound and single-based fertilizers on shelf life of exotic/minor vegetable crops cultivated for the fresh market. The reference crops were lettuce (var. Eden), carrot (var. Bahia), and sweet pepper (var. Yellow wonder); for leafy, root, and fruit vegetable categories respectively. Lettuce represented leafy and succulent vegetables including leafy vegetables, stem vegetables, and floral vegetables/immature flower parts; sweet pepper represented fruit vegetables including immature and mature fruit vegetables with seeds; and carrot represented bulky vegetative organs or underground structures including roots, tubers, bulbs, rhizomes, and corms.

\section{Materials and methods}

\section{Laboratory studies}

Laboratory studies were conducted to ascertain the shelf life of fresh lettuce, sweet pepper, and carrot as influenced either by a single- based fertilizer or a compound fertilizer. The objective was for the fresh market.The studies were carried out at the Chemistry Laboratory of the Savannah Agricultural Research Institute (SARI) of the Council for Scientific and Industrial Research (CSIR), Nyankpala - Tamale, Northern Ghana; Water Research Institute (WRI), Tamale, Ghana; and the Spanish Laboratory of University for development studies (UDS), Nyankpala Campus, Tamale, Ghana; since these laboratories were relatively well equipped for the required studies. It is also for the reason that these laboratories were comparatively near the field-study area for convenience and ease of transportation.

For every harvest (samples) made, fruits were immediately road-transported from the field to the laboratory for the assessments under recommended refrigerated conditions. ${ }^{15,16}$ Distances of one and a half kilometres $(1.5 \mathrm{~km})$, fifteen kilometres $(15 \mathrm{~km})$, and one hundred meters $(100 \mathrm{~m})$ to the laboratories at SARI, WRI, and UDS, respectively, were covered from the field. The experiment was conducted following Completely Randomized Design (CRD) with four replications.

\section{Soil test}

The experimental soil was tested for $\mathrm{N}(0.07 \%), \mathrm{P}(3.35 \mathrm{mg} / \mathrm{kg})$, $\mathrm{K}(0.24 \mathrm{mg} / \mathrm{kg}), \mathrm{Ca}(2.08 \mathrm{Cmol}+\mathrm{kg}), \mathrm{Mg}(0.52 \mathrm{mg} / \mathrm{kg}), \mathrm{pH}(5.26)$, and $\mathrm{EC}(114.50 \mu \mathrm{s} / \mathrm{cm})$ to determine the nutrient status of the soil; for the fact that some of these elements were included in the different fertilizers applied in the study. Soil $\mathrm{pH}$ was also tested for, before land preparation since it is a determinant of soil fertility status ${ }^{17}$ and as well reflects the degree of acidity or alkalinity of the soil. ${ }^{18}$ The results of the soil analyses dictated the types of basic fertilizers and quantities applied, taking into account the requirements specific to each test crop. ${ }^{19,20}$

\section{Determination and definition of damage or damage factors}

This was accomplished as outlined by $\mathrm{Abu}^{21}$ who indicated that to determine what damage is, a unit sample is defined as either slightly damaged, undesirably coloured, or sound as damage factors. The shelf-life of any unit sample that was slightly damaged or undesirably coloured was terminated.

The slightly damaged were further grouped into three, comprising: slightly physiologically damaged (wrinkles, shrinkage, and softening due to wilting and other physiological stresses); slightly pathologically damaged (sunken spots, rotting, mycelia growth, and disease symptoms due to bacterial and fungal infections); and slightly mechanically damaged (cuts, punctures, scuffs, and abrasions as open wounds, and bruises due to impacts, compressions, and vibrations that samples may encounter in storage).

Undesirably coloured samples were those with poor/abnormal colour.

Sound samples were those free from any damage(s).

These criteria and method ${ }^{21}$ were applied in the determination and definition of damage or damage factors in each case of the different test crops for results under the current shelf-life study.

\section{Sampling and determination of shelf-life}

Sound freshly harvested lettuce, sweet pepper, and carrot were sampled and stored under recommended refrigerated conditions ${ }^{15,16}$ for the shelf-life assessments. Tests were carried out according to the physiological maturity times for the different test crops and then replicated four times in relation to the four replicates to which each treatment was subjected to. 
For the shelf-life test, the different test crops were randomly picked from each treatment (either Single-based fertilizer treated, Compound fertilizer treated, or no fertilizer treatment ie. Control) and put into open plastic containers under recommended refrigerated conditions. A sample of each treatment consisted of ten (10) sound harvested plants in the case of lettuce; ten (10) sound harvested fruits in the case of sweet pepper, and ten (10) sound harvested root tubers in the case of carrot. This is to justify subsequent presentations and observations of research results that allow appropriate discussion and conclusion(s).

The different vegetable crop samples placed under recommended refrigerated conditions for tests were examined and rotated daily and those found to be damaged after each day's examination were discarded. The number of days each unit of a sample took to show any sign of damage was recorded as the shelf life, and the affected unit sample(s) discarded from the lot, up to the last unit sample. The mean number of days (sum of days taken for each unit sample to be discarded from the lot divided by the total number of units in each sample) was calculated and recorded as the shelf-life time for the sample in the particular treatment. All determinations were replicated four times.

\section{Experimental treatments and statistical analyses}

There were five (5) treatments in each case of a test crop. The following is an outline of the treatments for:

\section{Lettuce}

$50 \mathrm{~g}$ of ammonium sulphate $(20.5 \% \mathrm{~N} 23.4 \% \mathrm{~S}) /$ plot of $2.7 \times 2.6$ m OR $71 \mathrm{~kg}$ of ammonium sulphate (20.5\% N $23.4 \% \mathrm{~S}) / \mathrm{ha}$

$70 \mathrm{~g}$ of ammonium sulphate $(20.5 \% \mathrm{~N} 23.4 \% \mathrm{~S}) /$ plot of $2.7 \times$ $2.6 \mathrm{~m}$ OR $100 \mathrm{~kg}$ of ammonium sulphate $(20.5 \% \mathrm{~N} 23.4 \% \mathrm{~S}) / \mathrm{ha}$

$90 \mathrm{~g}$ of ammonium sulphate $(20.5 \% \mathrm{~N} 23.4 \% \mathrm{~S}) /$ plot of $2.7 \times$ $2.6 \mathrm{~m}$ OR $128 \mathrm{~kg}$ of ammonium sulphate $(20.5 \% \mathrm{~N} 23.4 \% \mathrm{~S}) / \mathrm{ha}$

$246 \mathrm{~g}$ of NPK (15-15-15)/plot of $2.7 \times 2.6 \mathrm{~m}$ OR $350 \mathrm{~kg}$ of NPK (15-15-15)/ha after Swiader et al. ${ }^{22}$ and Fageria. ${ }^{20}$

Control $=$ No treatment/fertilizer application per plot of $2.7 \times 2.6$ $\mathrm{m}$

\section{Sweet pepper}

$57 \mathrm{~g}$ of 6-24-12 NPK/plot of $2.7 \times 2.6 \mathrm{~m}$ OR $\mathbf{8 1} \mathbf{~ k g}$ of 6-24-12 NPK/ha

$77 \mathrm{~g}$ of 6-24-12 NPK/plot of $2.7 \times 2.6 \mathrm{~m} \mathrm{OR} \mathbf{1 0 0} \mathbf{~ k g ~ o f ~ 6 - 2 4 - 1 2 ~}$ NPK/ha

$97 \mathrm{~g}$ of 6-24-12 NPK /plot of $2.7 \times 2.6 \mathrm{~m}$ OR $\mathbf{1 3 8} \mathbf{~ k g ~ o f ~ 6 - 2 4 - 1 2 ~}$ NPK /ha

$158 \mathrm{~g}$ of NPK (15-15-15)/plot of $2.7 \times 2.6 \mathrm{~m}$ OR $225 \mathbf{~ k g ~ o f ~ N P K ~}$ (15-15-15)/ha after Swiader et al. ${ }^{22}$ and Fageria. ${ }^{20}$

Control $=$ No treatment/fertilizer application per plot of $2.7 \times 2.6$ $\mathrm{m}$

\section{Carrot}

$30 \mathrm{~g}$ of 10-10-30 NPK/plot of $2.7 \times 2.6 \mathrm{~m}$ OR $43 \mathbf{~ k g ~ o f ~ 1 0 - 1 0 - 3 0 ~}$ NPK/ha

$50 \mathrm{~g}$ of 10-10-30 NPK / plot of $2.7 \times 2.6 \mathrm{~m}$ OR $71 \mathbf{~ k g ~ o f ~ 1 0 - 1 0 - 3 0 ~}$ NPK/ha

$70 \mathrm{~g}$ of 10-10-30 NPK /plot of $2.7 \times 2.6 \mathrm{~m}$ OR $100 \mathrm{~kg}$ of 10-10-30 NPK/ha
$158 \mathrm{~g}$ of NPK (15-15-15)/plot of $2.7 \times 2.6 \mathrm{~m}$ OR $225 \mathrm{~kg}$ of NPK (15-15-15)/ha after Swiader et al..$^{22}$ and Fageria. ${ }^{20}$

Control $=$ No treatment/fertilizer application per plot of $2.7 \times 2.6$ $\mathrm{m}$

Treatments 1, 2, 3, 4, and 5 were designated as Single 1, Single 2, Single 3, Compound, and Control respectively, in each case of the three (3) different test crops for convenience in results' presentation, observation, and subsequent discussion.

All data were analyzed using the Analysis of Variance (ANOVA) technique ${ }^{23,24}$ with the GENSTAT statistical program. Least Significant Difference (LSD) test at $5 \%$ probability level was used to determine treatment differences that occurred among treatments for each test crop.

\section{Results}

\section{Effect of single-based fertilizers and compound fertilizers on the shelf-life of fresh lettuce, carrot, and sweet pepper}

Lettuce harvested from Compound fertilizer treated plots recorded significantly $(\mathrm{p}<0.05)$ short shelf-life $(3$ weeks $)$ when compared to those harvested from Control, and to those harvested from Single 1, Single 2, and Single 3 fertilizer treated plots (Figure 1). There were no significant differences in shelf-life of lettuce among those harvested from Control, Single 1, Single 2, and Single 3 treatments; all four treatments recorded the same shelf-life (4 weeks) for lettuce (Figure $1)$.

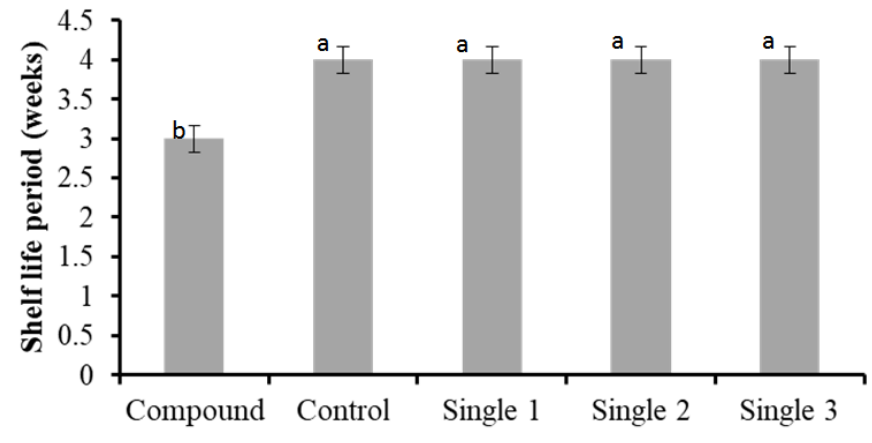

Various fertilizer treatments

Figure I Effect of various fertilizer treatments on the shelf-life of lettuce.

Bar values are means $\pm \mathrm{SEM} ; n=3$. Means with the same letters are not significantly different at $\mathrm{p}>0.05$.

Carrot roots harvested from Compound fertilizer treated plots recorded significantly $(\mathrm{p}<0.05)$ short shelf-life $(4$ weeks $)$ when compared to those harvested from Control, and to those harvested from Single 1, Single 2, and Single 3 fertilizer treated plots (Figure 2). There were no significant differences in shelf-life of carrot roots among those harvested from Control, Single 1, Single 2, and Single 3 treatments; all four treatments recorded the same shelf-life (5 weeks) for carrot roots (Figure 2).

A similar observation was made during shelf-life analysis for sweet pepper fruit where those harvested from the Compound fertilizer treated plots recorded significantly $(\mathrm{p}<0.05)$ short shelf-life $(2$ weeks) when compared to those harvested from Control, and to those harvested from Single 1, Single 2, and Single 3 fertilizer treated plots (Figure 3). Also, there were no significant differences in shelf-life of sweet pepper fruits among those harvested from Control, Single 1, 
Single 2, and Single 3 treatments; all four treatments recorded the same shelf-life (3 weeks) for sweet pepper fruits (Figure 3).

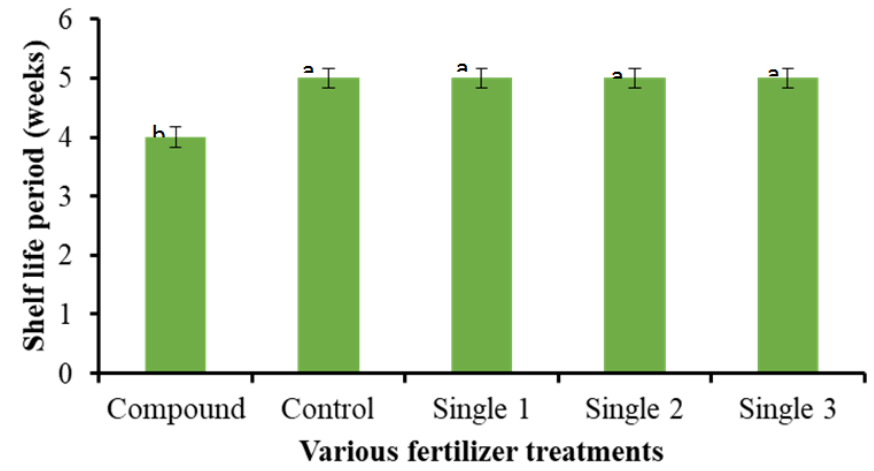

Figure 2 Effect of various fertilizer treatments on the shelf-life of carrot.

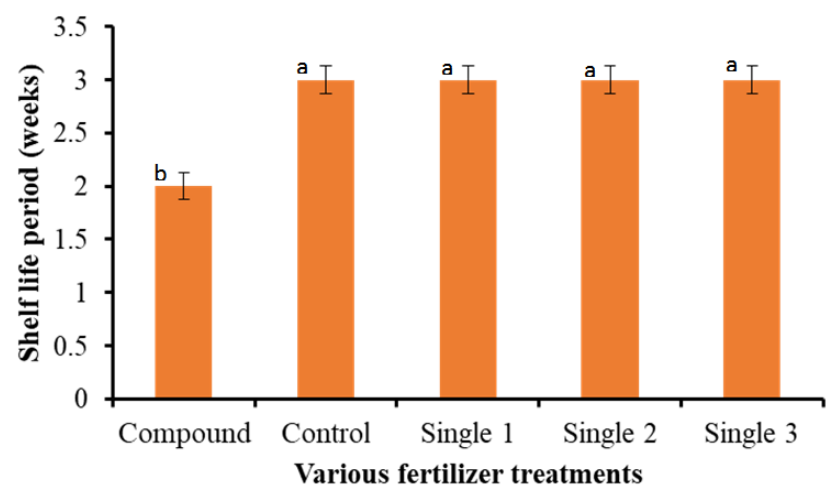

Figure 3 Effect of various fertilizer treatments on the shelf-life of sweet pepper.

Bar values are means $\pm \mathrm{SEM} ; n=3$. Means with the same letters are not significantly different $(\mathrm{p}>0.05)$.

Bar values are means $\pm \mathrm{SEM} ; n=3$. Means with the same letters are not significantly different $(\mathrm{p}>0.05)$

With sweet pepper fruits, those harvested from the Compound fertilizer treated plots gave a significantly $(p<0.05)$ short shelf-life ( 2 weeks) when compared to those harvested from Control, Single 1, Single 2, and Single 3 fertilizer treated plots. These four treatments recorded significantly indifferent shelf-lives (3 weeks) for sweet pepper fruits (Figure 3).

\section{Discussion}

\section{Effect of single-based fertilizers and compound fertilizers on the shelf-life of fresh lettuce, carrot, and sweet pepper}

Shelf-life was significantly decreased by the application of Compound fertilizer (NPK: 15-15-15) when compared to the application of the different Single-based fertilizers and to the Control in each case of lettuce, carrot, and sweet pepper vegetable crops. According to Brady and Weil, ${ }^{13}$ since nitrogen, phosphorus, and potassium generally must be in the inorganic forms to be taken up by plants, inorganic fertilizers are generally immediately bioavailable to plants without modification. These authors however added that some other authors have criticized the use of inorganic fertilizers with the claim that the water-soluble nitrogen doesn't provide for the long-term needs of the plant but creates water pollution which results in infected produce with short shelf life. The present finding corroborates previous studies which showed that increased nitrogen application had been associated with storage disorders and poor quality of harvested produce. ${ }^{3}$ This assertion could be possible for all the test crops under study. An additional probable reason for the poor shelf-life encountered by lettuce could be its shallow root system which would not have enabled the crop the required moisture content to synthesize the compound fertilizer appropriately -particularly as it was cultivated during the dry season under irrigation.

Plant growth and shelf life of produce are typically limited by nitrogen, phosphorus, and potassium just as low levels of carbon dioxide can also act as a limiting factor in the same vein. Studies have shown that increasing $\mathrm{CO}_{2}$ is highly effective at promoting plant growth and shelf life up to levels of over $300 \mathrm{ppm}$ after which further increases can, to a very small degree, continue to increase net photosynthetic output which leads to poor crop and subsequent poor shelf life. ${ }^{24}$ Findings from MIWQ ${ }^{25}$ indicated that when soil is irrigated with low $\mathrm{pH} /$ acidic water, the useful salts $(\mathrm{Ca}, \mathrm{Mg}, \mathrm{K}$, $\mathrm{P}, \mathrm{S}$, etc.) are removed by drainage water and unwanted aluminium and manganese salts are dissolved from the soil, thus impeding plant growth and subsequent shelf life. In generality, findings by MIWQ ${ }^{25}$ are a highly likely cause of the significantly low shelf life of fruits of the three different test crops in this study since the experimental soil for this study recorded $\mathrm{pH}$ reading of 5.26 - implying an acidic soil medium.

Sims ${ }^{10}$ reported that nitrogen is important for enhanced yield, but if optimum rates are exceeded it can have a negative impact on storage quality. According to this author, excess nitrogen can result in low dry matter content - which reduces the storage quality and can lead to disease(s) in the stored crop, especially in susceptible varieties.

Lettuce lived in shelf for four weeks after harvest from its Control and the other different levels of the Single-based nitrogen (ammonium sulphate: $20.5 \% \mathrm{~N} 23.4 \% \mathrm{~S}$ ) fertilizer treatments, but lived in shelf for three weeks after harvest from its Compound fertilizer treatment; carrot lived in shelf for five weeks after harvest from its Control and the other different levels of the Single-based potassium (10:10:30 NPK) fertilizer treatments, but lived in shelf for four weeks after harvest from its Compound fertilizer treatment; and sweet pepper lived in shelf for three weeks after harvest from its Control and the other different levels of the Single-based phosphorus (6:24:12 NPK) fertilizer treatments, but lived in shelf for two weeks after harvest from its Compound fertilizer treatment. Earlier reports by Sinnadurai ${ }^{19}$ \& Grubinger ${ }^{26}$ however, indicate shelf-lives of fresh lettuce, fresh carrot, and fresh sweet pepper to conform with the present findings, but not with the findings concerning Compound fertilizer application treatments. The present findings also suggest that Single-based fertilizers favour shelf-life of vegetables as compared to Compound fertilizers where lettuce, carrot, and sweet pepper were the reference crops.

Workneh and Osthoff ${ }^{27}$ however reiterated that horticultural crops are very diverse in morphological structure (roots, stems, leaves, flowers, fruits), in composition, and in general physiology; and that commodity requirements and recommendations for maximum postharvest life, therefore, vary among the various groups of vegetables.

The Single-based N fertilizer \{ammonium sulphate (20.5\% N 23.4 $\% \mathrm{~S})\}$ and its Control treatment resulted in significantly high shelf life with the Compound fertilizer treatment recording a comparatively short shelf life for lettuce in store. Hoque et al. ${ }^{28}$ reported similar results. Other studies found that high rates of $\mathrm{N}$ reduced the soluble sugar content and increased the acid-sugar ratio for a balance which lowered the sugar content in lettuce for enhanced acceptable taste from 
a culinary point of view. ${ }^{17}$ Lodhi et al. ${ }^{29}$ however speculated that high sugar content could also bring about moderate respiration and a lower degradation rate of chlorophyll during storage. According to Tyagi et al. ${ }^{30}$ high $\mathrm{N}$ content induces reduction in post-harvest life as a result of increased susceptibility to mechanical damage, physiological disorders, and to tissue decay. These in turn increase the severity of bacterial infection and resultant short shelf life. It is therefore possible that the level of $\mathrm{N}$ in the Compound fertilizer played a key role in the early deterioration of lettuce in store as against the Single-based N fertilizer and the Control treatments.

Compound fertilizer (NPK 15:15:15) application resulted in a significantly short shelf-life (4 weeks) for carrot roots in the cold store relative to the different rates/levels of the Single-based potassium fertilizer (10:10:30 NPK) and its Control. Shibairo et al. ${ }^{18}$ reported that increased $\mathrm{K}$ application reduced the post-harvest moisture loss in carrot during a short-term storage which was determined by the maintenance of tissue integrity in the carrot root. The storage life of carrot root increased with the Single-based K fertilizer (10:10:30 NPK) treatment probably because it is a requirement (fertilizer-type and quantity) specific to carrot as a root vegetable. Poor management of fertilizer scan cause physiological disorders and even toxicity due to deficiencies of some nutrients.

Singh et al. ${ }^{1}$ reported that $\mathrm{K}$ application increased photosynthetic activity in fruits and vegetables and led to the accumulation of carbohydrates and subsequent increase in yield and shelf-life. The authors added that deficiency of $\mathrm{K}$ led to quality deterioration following previous heavy flower and fruit drop. Imas ${ }^{31}$ indicated that root crops viz. potato and carrot cultivated with NPK fertilizer application had poor shelf life than those grown without fertilizer.

Nair ${ }^{14}$ indicated that potassium fertilization directly influences many critical physiological processes such as photosynthesis, carbohydrate transport, and water regulation. Managing optimum levels of potassium in the soil and the plant, leads to improved disease resistance, increased drought tolerance, and vigorous vegetative growth. As a result, potassium fertilization is frequently associated with improved crop quality and shelf life. ${ }^{14}$ Imas $^{31}$ reiterated that adequate potassium supply ensures more marketable crop with a healthy longer shelf life and less moisture loss during storage.

Sweet pepper fruits that were harvested from the Compound fertilizer treated plots lived a significantly short shelf-life ( 2 weeks) when compared to those harvested from Control, Single 1, Single 2, and Single 3 phosphorus based (6-24-12 NPK) fertilizer treated plots which recorded significantly indifferent shelf-lives (3 weeks).

Phosphorus is involved in several key plant functions including cell division, storage and transfer of energy, photosynthesis, regulation of some enzymes, translocation of sugars, starches, and carbohydrates, nutrient transport, and transfer of genetic characteristics from one generation to another. ${ }^{32}$ In the present study, increasing P availability increased shelf-life of sweet pepper. This agrees with Igbokwe et al. ${ }^{33}$ and Njira \& Nabwami ${ }^{34}$ who reported that vegetative growth, yield, and storage life of pepper improved significantly as a result of increased phosphorous fertilization. These authors speculated that the ability of $\mathrm{P}$ to affect physiological processes including translocation of sugars, carbohydrates, and protein synthesis resulted in the improved performances.

Nair $^{14}$ reiterated that shelf-life assessment is a collateral issue and interaction among nutrients can lead to deficiencies or toxicities. So, when you increase the dose of one nutrient you might cause a deficiency in another one and it would be difficult to interpret the results in terms of shelf life of the final product. It could be the result of the higher dose of the applied nutrient or the deficiency of another nutrient. ${ }^{14}$ Alhrout ${ }^{35}$ speculated thatsince deficiency of nutrients can cause deteriorationin fruits and vegetables, sufficient nutrition can increase shelf life, however, depending on the nutrient(s) concerned. For example, $\mathrm{Ca}$ and $\mathrm{K}$ may increase fruit shelf life while increasing $\mathrm{N}$ content can reduce it; other non-essential nutrients such as Si may also increase fruit shelf life. ${ }^{35}$ According to Dubey et al..$^{36}$ harvest stage as well as other preharvest conditions including irrigation, sunscalds, curing treatments, mechanical injuries, and genotype all influence shelf life. This is an interesting field of research to go through in details.

Lodhi et al. ${ }^{29}$ indicated that shelf life of fruits and vegetables depends on how good is the structure of the cells of the produce and the enzyme activities inside those cells. The structure of the cell walls depends on Ca content and the enzyme activities depend on the presence of some micro nutrients which act as co-enzymes. So, the presence or deficiencies of such nutrients and/or a balance between them will diffidently determine the shelf life of the produce Lodhi et al. ${ }^{29}$. Islam ${ }^{31}$ opined that to promote healthy aging, healthy nutrient environment is essential; and that nutrient composition of fruit and vegetables is dependent on soil health, plant health, production environment, and plants' own defence system. In Ghana it has been proven that farmers who used organic compost for their fruit and vegetable crop production could store the produce for a longer time than those who used chemical fertilizers. ${ }^{38}$

Phosphorus involved in several key plant functions, including cell division, storage and transfer of energy, photosynthesis, regulation of some enzymes, transformation of sugars and starches, nutrient transport within the plant, transport of carbohydrates, and transfer of genetic characteristics from one generation to another. ${ }^{32}$

\section{Conclusion}

Shelf life was significantly lowered by the application of Compound fertilizer (NPK 15-15-15) when compared to the different Single-based fertilizer treatments and the corresponding Controls in each case of lettuce, carrot, and sweet pepper storage. Lettuce lived in shelf for four weeks after harvest from its Control and the other different levels of the Single-based nitrogen (ammonium sulphate: $20.5 \% \mathrm{~N} 23.4 \% \mathrm{~S}$ ) treatments, but lived for three weeks after harvest from its Compound fertilizer treatment; carrot lived in shelf for five weeks after harvest from its Control and the other different levels of the Single-based potassium (10:10:30 NPK) treatments, but lived for four weeks after harvest from its Compound fertilizer treatment; and sweet pepper lived in shelf for three weeks after harvest from its Control and the other different levels of the Single-based phosphorus (6:24:12 NPK) treatments, but lived for two weeks after harvest from its Compound fertilizer treatment. Single-based fertilizers therefore favour long shelf life of vegetables relative to Compound fertilizers with lettuce, carrot, and sweet pepper as reference crops.

\section{Acknowledgments}

None.

\section{Conflicts of interest}

The authors have no conflict of interest for this research.

\section{References}

1. Singh S K, Singh R S, Awasthi O P. Influence of preharvest and postharvest treatments on shelf life and quality attributes of ber fruits. Indian journal of horticulture. 2013;70(4):610-613. 
2. Bekele D. Review on factors affecting postharvest quality of fruits. $J$ Plant Sci Res. 2018;5(2):180.

3. Barman K, Ahmad MS, Siddiqui MW. Factors affecting the quality of fruits and vegetables: Recent understandings. In: Siddiqui MW, editor. Postharvest biology and technologyof horticultural crops: Principles and practices for quality maintenance (p. 1-50). Waretown, NJ: Apple Academic Press. (taylorfrancis.com), 2015.

4. BeverlyR B, Latimer JG, Smittle D A. Preharvest physiological and cultural effects on postharvest quality. In: Shewfelt RL \& Prussia SE, editors. Postharvest handling: A systems approach. Academic, NewYork. 1993;73-98.

5. Salunkhe DK, Bolin HR, Reddy NR. Preharvest factors on postharvest yield and quality, In: Storage, processing and nutritional quality of fruits and vegetables. CRC Press, Boca Raton, 1991;1:7-44.

6. Lodhi Y, Chakravorty S, Prasad BVG, et al. Influence of nutrients and mulching on fruiting and fruit characteristics of bell pepper (Capsicum annum L.). The Pharma Innovation. 2019;8(6):791-794.

7. Nayyer MA, Siddiqui MW, Barman K. Quality of fruits in the changing climate. In: Choudhary ML, Patel VB, et al. editors. Climate dynamics in horticultural science: Impact, adaptation, and mitigation. Waretown, NJ: Apple Academic Press. 2015;2: 269-278.

8. Cuquel FL, Motta ACV, Tutida I, et al. Nitrogen and potassium fertilization affecting the plum postharvest quality. Rev Bras Frutic. 2011;33:328-336.

9. Salunkhe DK, Desai BB. Effects of agricultural practices, handling, processing and storage on vegetables. In Karmas E \& Harris RS, editors. Nutritional Evaluation of food processing.Van Nostr and Rein hold, NewYork. 1988;23-71.

10. Sims GK. Nitrogen starvation promotes biodegradation of N-heterocyclic compounds in soil. Soil Biology \& Biochemistry. 2006; 38:2478-2480.

11. Maynard DN. Fruit and vegetable quality as affected by nitrogennutrition. Proc Amer Soc Agron. 1984;617-626.

12. Johnson JR, McGuinn JR, Rushing JW. Influence of pre harvest factors on post harvest quality of pre-packaged fresh market spinach. Appl $A g r$ Res. 1989;4:141-143.

13. Brady N, Weil R. Nitrogen and sulfur economy of soils. In Helba (ed.), The Nature and properties of soils. Pearson Education, NJ. 2002;543-571.

14. Nair A. Importance of soil fertility in vegetable crop production. Iowa State University of science and technology. Extension and outreach on agriculture and natural resources - Small farm sustainability. 2018.

15. Tijskens LMM, Polderdijk JJ. A generic model for keeping quality of vegetable produce during storage and distribution. Agricultural Systems, 1996;51(4);431-452.

16. CCDC (Cold Chain Development Centre). Cold storage for fresh Horticulture produce requiring pre-cooling before storage (technical Standards number NHB -CS- Type 02-2010). National Horticulture Board (department of agriculture and cooperation ministry of agriculture gov't of India) 85, Institutional Area, Sector 18, Gurgaon -122015 (Haryana). 2010

17. Wang $\mathrm{ZH}$, Li S, Malhi S. Effects of fertilization and other agronomic measures on nutritional quality of crops. Journal of Science, Food and Agriculture. 2008;88:7-23.

18. Shibairo SI, Upadhyaya MK, Toivonen PMA. Potassium nutrition and postharvest moisture loss in carrots (Daucus carota L.). Journal of Horticultural Science and Biotechnology. 2015;73(6):862-866.

19. Sinnadurai S. Vegetable cultivation. Asempa Publishers. Advent Press, Accra, Ghana. 1992;1-208.
20. Fageria NK. The use of nutrients in crop plants, Taylor and Francis Group, Boca Raton, FL.2009.

21. Abu M. Quality criteria for mango export in ghana. PhD Thesis submitted to the school of graduate studies, kwame nkrumah university of science and technology (K.N.U.S.T.), Kumasi, Ghana. 2010;1-167.

22. Swiader JM, Ware GW, Mc Collum JP. Producing vegetable crops, 4thedn. Interstate publishers Inc. Danville, Illinois. 1992; 1-196.

23. Snedecor GW, Cochran WG. Statistical Methods, 7th ed. The Iowa State Univ. Press. Ames. Iowa. 1980;1-507.

24. Chapin FS, Pamela AM, Harold AMF. Principles of Terrestrial Ecosystem Ecology. New York: Springer. ISBN 0387954392, 2002.

25. MIWQ. Managing irrigation water quality (MIWQ), Oregon State University, USA.2012.

26. Grubinger VP. Truck farming; organic farming; vegetable marketing; fruit and vegetable production; small-scale farming. ithaca, n.y.: natural resource, Agriculture, and Engineering Service (NRAES), 2018.

27. Workneh TS, Osthoff G. A review on integrated agro-technology of vegetables. African Journal of Biotechnology. 2010; Vol. 9(54);93079327.

28. Hoque MM, Ajwa H, Othman M, et al. Yield and postharvest quality of lettuce in response to nitrogen, phosphorus, and potassium fertilizers. Hort Science. 2010;45(10):1539-1544.

29. Lodhi Y, Chakravorty S, Trivedi J. Effect of different nutrient levels and mulches on fruit quality and chlorophyll content of bell pepper (Capsicumannum L.). Inter. J.of Fauna and Biological Studies. 2019;6(4):29-31.

30. Tyagi S, Sahay S, Imran M, et al. Pre-harvest factors influencing the post harvest quality of fruits: a review. 2017.

31. Imas P. International Potash Institute (IPI), 2013; ISBN 978-3-905887-075DOI 10.3235/978-3-905887-07-5.

32. Taiz L, Zeiger E, Moller I M, et al. Plant Physiology and development. 6th Edition, Sinauer Associates, Sunderland, CT,2015.p 761.

33. Igbokwe GE, Aniakor GC,Anagonye CO. Determination of $\beta$-Carotene and Vitamin C content of Fresh Green Pepper (Capsicumannnum), Fresh Red Pepper (Capsicumannum) and Fresh Tomatoes (Solanumlycopersicum) Fruits. Bio-scientist. 2013;1;89-93.

34. Njira KO, Nabwami J. A review of effects of nutrient elements on crop quality. African Journal of Food, Agriculture, Nutrition and Development. 2015;15(1):9777-9793.

35. Alhrout HH. Response of growth and yield components of sweet pepper to two different kinds of fertilizers under green-house conditions in Jordan. Journal of Agricultural Science. 2017;9(10):265-272.

36. Dubey AK, Singh D, Rajput P, et al. Effect of NPK on plant growth, yield and quality of Capsicum (Capsicum annum L.) c.v.Swarna under shadenet condition. Int J Curr Microbiol App Sci. 2017;6(3):1085-1091.

37. Islam MdR, Sultana T, Haque MdA, et al. Growth and yield of chilli influenced by nitrogen and phosphorus. IOSR Journal of Agriculture and Veterinary Science. 2018;11(5):54-68.

38. Allan VJ. The extent of organic and inorganic farming practices as adopted by vegetable farmers in the Northern region of Ghana. MSc Thesis submitted to the Graduate School, University for Development Studies, Tamale, Ghana. 2018;1-125. 